\title{
The Seventh Finance Commission and Its Fault Lines
}

\author{
S. N. Misra ${ }^{1} \&$ Sanjaya Ku. Ghadai ${ }^{2}$ \\ ${ }^{1}$ School of Leadership, KIIT University, Campus-4, Bhubaneswar, Odisha, Pin-751024, India \\ ${ }^{2}$ School of Leadership, KIIT University, Campus-4, Chintan Building, Patia, India \\ Correspondence: S. N. Misra, School of Leadership, KIIT University, Bhubaneswar, Odisha, Pin-751024, India. \\ Tel: 738-110-9899. E-mail: misra.sn54@gmail.com
}

Received: January 28, 2016

Accepted: February 3, 2016

Online Published: February 29, 2016

doi:10.20849/ajsss.v1i1.20

URL: http://dx.doi.org/10.20849/ajsss.v1i1.20

\begin{abstract}
Bureaucracy is a vital institutional cog to foster Gross Domestic Product (GDP) and promote Human Development Index (HDI) in India. Of late its dysfunctionality and sub-serving character has been dismaying discerning sociologists like Merton \& Parsons. The Seventh Finance Commission has also lamented this aspect while providing a bonanza to all, extending One Rank One Pension (OROP) to all categories of pensioners and improving the living conditions of the Group " $\mathrm{C}$ " employees. The paper brings out the novel aspects of the report like its emphasis on Skill India but laments about its inadequate attention to aspects like burgeoning Fiscal Deficit (FD) and lack of concern to improve productivity. The paper calls upon bureaucracy to follow the Weberian approach of being apolitical, rational and foster the process of shared prosperity through Rule of Law.
\end{abstract}

Keywords: GDP, HDI, OROP, FD, skill India

\section{Introduction}

Weber inked the architecture of bureaucracy by calling it "rational, legal, impersonal" with a view to enforcing rule of law with efficiency and economy. He also underlined the importance of specialized qualification. The Seventh Pay Commission begins by invoking the ancient scriptures and Chanakya to establish "Dharma in all walks of life", as they lament the steep decline of our administrative machinery. Several discerning social scientists have lamented the dysfunctional character of bureaucracy like "sub-serving personal position" (Selznick), mismatch in skills and orders from the top (Parsons). The general perception of the lay public is not far different; as the bureaucrats are considered politically pliant, urban centric and ineffective in delivering myriad social and economic sector programs that dot the hopes and aspiration of the marginalized.

This paper tries to analyze (a) major recommendations of the seventh Finance Commission (b) its novel features and the fault lines (c) The road forward.

\section{Major Recommendations}

The Grade "C" employees in Government of India (GOI) constitute $88 \%$ of the workforce. They would get a minimum pay of Rs.18000/- while the maximum pay scale of a Cabinet Secretary would be Rs.2.5 lakh, i.e. an income differential of 1:14. The mark up over the basic pay of 2006 would be in the range of 2.57-2.72 times for different categories, with higher mark up for Grade "A" employees. The Pay Allowance Pension (PAP)/GDP will increase by $0.65 \%$ i.e. Rs.1.02lakh crore. It will benefit around 47 lakh civil and defence personnel and 52 lakh pensioners with an average benefit of $24 \%$ over their last pay and pension. The most significant recommendation has been to extension of One Rank One Pension principle to all categories of employees; thereby eliminating the patently discriminating anomaly of extending OROP provision only to the defence personnel.

\section{A Macro Profile of the Civil Services}

Article 309 provides the architecture for recruitment and conditions of service for the Civil Servants, who are expected to execute the laws enacted by the union and the states. They are the steel frame of the government and carry a substantial institutional legacy from the Britishers. While the authorized strength of the civil services at various levels is around $40 \mathrm{Lakh}$, the posted strength shows a deficiency of nearby $20 \%$. The profile of posted strength of major departments, defence services and the pensioners is placed below: 
Table 1. Posted strength of civil, defence services \& pensioners (in lakhs)

\begin{tabular}{lll}
\hline Sl. No. & Parameter & Strength \\
\hline (A) & Strength of Civilians & 33.02 \\
(i) & Railway & 13.16 \\
(ii) & MHA & 9.8 \\
(iii) & Defence & 3.98 \\
(B) & Strength of Defence Services & 13.86 \\
(C) (A+B) & Total Strength & 46.88 \\
(D) & Total Pensioner & 51.96 \\
(E) (C+D) & Total Strength & 98.84 \\
\hline
\end{tabular}

Source: $7^{\text {th }}$ Pay Commission

It would be seen from the above that the total strength of serving government employees and pensioners is around 98.8 lakh, with a dominant presence of the defence and railway personnel. The paramilitary forces also have a substantial presence. Assuming an average family size of 5, the services constitute a sizable presence (500 million) of the national economy and its policy foot prints. The pay and allowances and pension commitment of the government is profiled below.

Table 2. Expenditure on P\&A and pension: civil \& defence

\begin{tabular}{ll}
\hline Parameter & Amount in Rs. Crore \\
\hline 1. Civil Personnel & 129600 \\
2. Defence Personnel & 51000 \\
Sub Total & 180600 \\
3. Pension & 104101 \\
4. Total Expenditure & 284701 \\
\hline
\end{tabular}

Source: Seventh pay commission and defence services estimates

It would be seen that around Rs. 2.84 lakh is spent on pay and pension, constituting nearly $1.8 \%$ of our GDP. The extra expenditure, on adaption of the $7^{\text {th }}$ Pay Commission Report, would be Rs.1.02 lakh crore, which would increase the share of pay and pension in the GDP to $2.45 \%$. This has to be seen in the backdrop of India's revenue and fiscal deficits, which is as under

Table 3. Macro fiscal position (as \% to GDP)

\begin{tabular}{llll}
\hline Parameter & $15-16$ & $16-17$ & $17-18$ \\
\hline Revenue Deficit & 2.8 & 2.4 & 2.0 \\
Fiscal Deficit & 3.9 & 3.5 & 3.0 \\
Gross Liability & 46.1 & 47.7 & 42.8 \\
\hline
\end{tabular}

Source: India's Budget 2015-16

The Greek crisis recently had its genesis in its Debt/GDP exceeding 100\%. The Rogoff Reinhart theorem had underscored the negative impact on growth when debt exceeds $90 \%$. India, with a total central state debt of $67 \%$, has to be cognizant of the dangers lurking such fiscal bonanza.

There is understandable jubilation in sectors like automotives and construction sectors. On the flipside its impact on cost-push inflation is not to be discounted, as these pay increase are not going to lead to any commensurate increase in productivity. Every P.C. report brings with a cycle of demand pull and cost push and pushes the FM 
on a bumpy ride with fiscal deficits.

\section{Novel Features of the Seventh Finance Commission}

\subsection{Rationale for a Minimum Pay}

The Committee bases its criteria, based on a calorific norm of 2700 of Dr. Wallace $R$. Aykroyd, an international expert in nutrition. This is $12 \%$ more than the 2400 calories suggested by the Tendulkar Committee. It also suggests that $65 \mathrm{gms}$ of protein should be part of the diet for each member of the family. It thus goes beyond poverty line to a decent line of living. Most heartrendingly, it factors in $20 \%$ for skill up gradation of government servants at the lowest level of the bureaucratic pyramid. The weightage for food has been put at $51 \%$ which is in consonance with the weightage of $48 \%$ in CPI, which is now the template for public policy as per the Urjit Patel Committee Report (2013).

\subsection{One Rank One Pension for All}

This is the most egalitarian recommendation, as it will guarantee same pension to similarly placed personnel irrespective of the year they joined the service. It takes the famous D. S. Nahra Vs. UOI (1983) judgement to its logical conclusion, where the judges had wisely struck down the arbitrary classification of "homogenous class". The pensioners deserve equal protection under Article 14, once they have served in a similar manner.

\subsection{Fresh Look at the New Pension Scheme}

The Commission has wisely drawn the attention to the need for handling and deploying pensionery fund of those who have joined the New Pension Scheme after 2004, more prudently. Presently 13lakh government servants have joined the scheme and the pension fund carries of capital base of 24,000 cr. However, the return to the employees is a paltry $9.1 \%$ per annum, as most of the fund is deployed in government securities. An interesting global example is that of Chile where the average of return on pension fund (81-86) was over $12.8 \%$ in real terms as it was managed by private companies more professionally and proficiently with government oversight. It makes eminent economic sense to put pension fund in investment of infrastructural projects where India is in need of $\$ 1$ trillion during the $12^{\text {th }}$ plan. With bond market, slow to develop and with a tepid market for equity, pension fund needs to be managed more prudently.

\subsection{Accountability and Productivity}

The Chairman draws reference the BN Hazarika Vs. State of Assam (2013) to underscore the point that "legitimate aspiration of the employees should not be guillotined". The Commission goes one step forward by draw reference to the wider bureaucratic coverage in USA (670 per lakh) to (140 per lakh) in India. This is an argument which will make Parkinson turn in his graves as it completely overlooks the coverage, quality and accountability aspects of the federal services in USA vis-à-vis the poor outcome oriented structure of our bureaucracy. Prof. Rakesh Mohan, in a perceptive article to Indian Policy Forum (2013-14), had brought out how the "Underlying theme encompassing most constraints in India is the lack of adequate delivery of public services in both quality and quantity". To implement the second generation of reforms and deliver on the myriad social sector programs, the challenge is not how to increase the size of the civil services, but how to outsource most of these services to credible private agencies who will put a premium on performance. The other challenge is how to encourage specialization, capability buildup within the civil services and offer attractive packages both at entry point and to those who excel during their services. Prof. Rajan, in his annual review of RBI 2015-2016 has underscored this as a key factor.

\subsection{Needless Needling of the Defence Services}

The report, based on an IDSA study, has brought out how the defence services are paid very handsomely, on a global scale.

Table 4. Salary comparison of defence services globally (at \$PPP)

\begin{tabular}{llll}
\hline Category & USA & UK & India \\
\hline Sepoy & 1416 & 1726 & 1361 \\
Lt. Col & 7500 & 8176 & 6866 \\
General & 15125 & 22489 & 11701 \\
\hline
\end{tabular}

Source: Seventh pay commission 
The committee observes that with a per capita difference of 10:1 (USA \& India), such pay package by the services is enviable. It's true that the defence services enjoy a number of additional benefits like free rations, rank pay and subsidized canteen items, compared to their civilian counterparts. However, the three wars and the looming Low Intensity Conflict (LIC) have proved, how as a disciplined entity they have risen to the challenge much better than other institutions. Ajai Shukla has lamented the attempt on the part of the IAS to bolster the package of IPS and IFOs by doing down the services.

\section{Road Ahead}

Prof. Upenda Buxi, a distinguished jurist, calls bureaucracy and the legislature, as the "imperious arms of the government". Striking down the NJAC as volatile of the basic structure, the judges have proved that they can not only be imperious; but impervious to basic logic. The reasons are not far to find as 1975 was a watershed movement for them when Mrs. Gandhi wanted a 'committed judiciary'. The judges did cave in the infamous ADM Jabalpur Case (1976) when they chirmed in with the executive that "right to life during extinguishes emergency". However, they have bounced back with unusual vigour by promoting PIL.

The judges enjoy constitutional immunity through Article 125(2) and can be removed only through an elaborate impeachment procedure i.e. Article 124(4). On the other hand, though Article 311 provides Civil Servants a reasonable opportunity to defend themselves, it does not provide any institutional autonomy brought out how improper orders were carried out by senior Civil Servants with an eye on political patronage.

The earlier pay commission had recommended several innovative features to ensure a better delivery system in the government. Performance Related Incentive Systems (PRIS) was one such step. They have remained pipe dreams. The Civil Services Day chaired by the PM have become acts of tokenism. The Seventh Finance Commission resuscitates this dream and recommends performance related pay based on a Results Frame Work Document. Each pay commission brings with it, its high points; the sixth PC brought Rank Pay for the Defence Services; the present PC, OROP all categories of pensioners. The last commission cost the exchequer an additional Rs.12561 crore to the exchequer and the present would cost 8 times more. Ironically, the $7^{\text {th }}$ pay commission makes no serious reference to fiscal discipline, or improvement in productivity. Its invocation to our ancient scriptures "where there is dharma, there is victory" and its unilateral pitch for higher pay for civil servants sadly underplays the concerns that every common Indian has in terms of time bound, result oriented civil service. The Civil Services are a vital cog in democracy. It has to play the independent regulator in an increasingly market oriented economy. But an unfettered market as Prof. Joseph Stiglitz rightly observes "will lead to more monopoly power, more abuse of the financial sector and more unbalanced trade relations". The civil services with the latest bonanza would need to pause and think how they "will heal the great divide and ensure shared prosperity to all”.

\section{References}

$12^{\text {th }}$ Plan Document. Government of India.

$14^{\text {th }}$ Finance Commission Report. Government of India.

Banerjee, A., \& Duflo, E. (2013). Poor Economics. Random House Publishers India Pvt. Ltd, Noida.

Defence Services Estimates. Government of India.

Economic Survey 2014-2015. Government of India.

Human Development Report, 2014 - Sustaining Human Progress: Reducing Vulnerabilities and Building Resilience-UNDP.

Nilekani, N., \& Shah, V. (2015). Rebooting India-Realizing a Billion Aspirations. Penguin Books India Pvt. Ltd.

Ninan, T. N. (2015). The Turn of the Tortoise-The Challenge and Promise of India's Future. Penguin Books India Pvt. Ltd. Haryana.

Second, Administrative Reforms Commission (2005). Government of India.

Selznick, P. Leadership in Administration: A Sociological Interpretation. University Of California Press.

Seventh Pay commission Report. Government of India.

Shukla, A. (2015). A hammer blow for the military. Business Standard.

Stiglitz, J. E. (2015). The Great Divide. Penguin Random House, UK.

Weber, M. (2014). The Protestant Ethic and the Spirit of Capitalism. Merchant Books. 


\section{Copyrights}

Copyright for this article is retained by the author(s), with first publication rights granted to the journal.

This is an open-access article distributed under the terms and conditions of the Creative Commons Attribution license (http://creativecommons.org/licenses/by/3.0/). 